\title{
Modelling coral polyp calcification in relation to ocean acidification
}

\author{
S. Hohn ${ }^{1}$ and A. Merico ${ }^{1,2}$ \\ ${ }^{1}$ Leibniz Center for Tropical Marine Ecology, Systems Ecology, Fahrenheitstraße 6, 28359 Bremen, Germany \\ ${ }^{2}$ Jacobs University Bremen, School of Engineering and Science, Campus Ring 1, 28759 Bremen, Germany \\ Correspondence to: S. Hohn (soenke.hohn@zmt-bremen.de)
}

Received: 14 February 2012 - Published in Biogeosciences Discuss.: 9 March 2012

Revised: 12 October 2012 - Accepted: 21 October 2012 - Published: 13 November 2012

\begin{abstract}
Rising atmospheric $\mathrm{CO}_{2}$ concentrations due to anthropogenic emissions induce changes in the carbonate chemistry of the oceans and, ultimately, a drop in ocean $\mathrm{pH}$. This acidification process can harm calcifying organisms like coccolithophores, molluscs, echinoderms, and corals. It is expected that ocean acidification in combination with other anthropogenic stressors will cause a severe decline in coral abundance by the end of this century, with associated disastrous effects on reef ecosystems. Despite the growing importance of the topic, little progress has been made with respect to modelling the impact of acidification on coral calcification. Here we present a model for a coral polyp that simulates the carbonate system in four different compartments: the seawater, the polyp tissue, the coelenteron, and the calcifying fluid. Precipitation of calcium carbonate takes place in the metabolically controlled calcifying fluid beneath the polyp tissue. The model is adjusted to a state of activity as observed by direct microsensor measurements in the calcifying fluid. We find that a transport mechanism for bicarbonate is required to supplement carbon into the calcifying fluid because $\mathrm{CO}_{2}$ diffusion alone is not sufficient to sustain the observed calcification rates. Simulated $\mathrm{CO}_{2}$ perturbation experiments reveal decreasing calcification rates under elevated $p \mathrm{CO}_{2}$ despite the strong metabolic control of the calcifying fluid. Diffusion of $\mathrm{CO}_{2}$ through the tissue into the calcifying fluid increases with increasing seawater $p \mathrm{CO}_{2}$, leading to decreased aragonite saturation in the calcifying fluid. Our modelling study provides important insights into the complexity of the calcification process at the organism level and helps to quantify the effect of ocean acidification on corals.
\end{abstract}

\section{Introduction}

Rising atmospheric $\mathrm{CO}_{2}$ concentrations due to fossil fuel emissions and land use changes are well known perturbations to environmental scientists as well as to the general public (IPCC, 2007). About a quarter of the $\mathrm{CO}_{2}$ emitted in a year is absorbed by the oceans (Sabine et al., 2004). $\mathrm{CO}_{2}$ reacts with water to produce carbonic acid that further dissociates by releasing hydrogen ions (simply called protons in the following). This causes a drop in ocean $\mathrm{pH}$, a process termed "ocean acidification" (OA) (Caldeira and Wickett, 2003). How these changes in seawater chemistry affect the life of marine organisms is a matter of debate (Ridgwell et al., 2009; Ries et al., 2009).

Marine organisms that produce skeleton structures of calcium carbonate $\left(\mathrm{CaCO}_{3}\right)$ are thought to be most susceptible to OA (Doney et al., 2009) because precipitation and dissolution of $\mathrm{CaCO}_{3}$ (in the various mineral forms) are strongly dependent on the concentration of carbonate ions, which decreases with decreasing $\mathrm{pH}$ (Zeebe and Wolf-Gladrow, 2001). Given that coral reef ecosystems are dominated by calcifying organisms (Cohen and Holcomb, 2009), there is great concern that they may be strongly perturbed by changes in seawater carbonate chemistry. Even though tropical surface waters will not become undersaturated with respect to aragonite or calcite within the next $100 \mathrm{yr}$ (Orr et al., 2005; Hoegh-Guldberg et al., 2007), the changes in carbonate chemistry are expected to cause a decrease in coral calcification rates of up to $30 \%$, most probably turning many coral reefs into non-reef coral communities with zero or even negative calcium carbonate accumulation (Kleypas et al., 2001).

Corals are colonial organisms made up of individual polyps. A coral polyp consists of a bag-like invagination of two cell layers separated by a collagenous layer, the 
mesoglea (Fautin and Mariscal, 1991). The opening of the invagination, i.e. the mouth of the polyp, bears tentacles to capture food. The inner cell layer is called the endoderm and encloses the stomach or coelenteron. In a coral colony, the single neighboring polyps are connected with each other via the tissue of the coenosarc (Tambutté et al., 2011). The outer cell layer, the ectoderm, is divided into the oral ectoderm, facing the seawater, and aboral ectoderm, facing the coral skeleton. The aboral ectoderm is called calicoblastic epithelium and consists of specialized cells whose activity induces the extracellular formation of aragonite crystals forming the coral skeleton (Constantz, 1986), a process known as calcification. The calcifying fluid between the calicoblastic epithelium and the coral skeleton is separated from the seawater by up to four cell layers and is strongly controlled by the polyp's physiology (Cohen and Holcomb, 2009; Ries, 2011; McCulloch et al., 2012).

It has been shown that corals increase the $\mathrm{pH}$ in the calcifying fluid with respect to seawater (Al-Horani et al., 2003; Ries, 2011; Venn et al., 2011) by actively removing protons from the calcifying fluid (Ries, 2011). There is also evidence that corals elevate calcium concentrations in the calcifying fluid with respect to their growth environment (Al-Horani et al., 2003), indicating active transport of calcium into the calcifying fluid (Cohen and McConnaughey, 2003; Allemand et al., 2004). Active calcium transport over cell membranes is common in eukaryotic cells (Inesi, 1985; Pedersen and Carafoli, 1987; Gussone et al., 2006). Calcium is required in the nucleus and is involved as second messenger in the signal transduction pathway (Carafoli, 2002). However, since calcium binds easily to organic molecules (also seen in Marshall et al., 2007), potentially disturbing cell physiological activity at elevated concentrations, the maintenance of very low intracellular concentrations, i.e. active removal of calcium ions from the cytoplasm against a concentration gradient, is an essential process (Carafoli, 1987). An ATPdriven calcium pump, or $\mathrm{Ca}^{2+}$-mediated ATPase (hereafter Ca-ATPase), has been identified in corals with genetic analyses and has been proven to exist in the calicoblastic epithelium cells (Zoccola et al., 2004). Kinetic activity measurements reveal saturating activity of the Ca-ATPase with increasing calcium concentrations, typical for ion transporters (Ip et al., 1991). Furthermore, the removal of protons from the calcifying fluid is likely connected to the activity of the calcium pump as the $\mathrm{Ca}^{2+}$-mediated-ATPase in eukaryotic cell membranes acts as a proton-calcium antiporter (Gould et al., 1986; MacLennan et al., 1997; Allemand et al., 2004). Therefore, the assumption of either a weak or a strong proton pump, or the maintenance of a constant proton gradient in corals (Ries, 2011) has implications for the calcium transport.

Besides a calcium transcellular route through the coral tissue, a paracellular pathway has been proposed where ions are transported between the seawater and the calcifying fluid via diffusion and/or advection through the intercellular space of the tissue (Tambutté et al., 2011). This paracellular pathway is mainly supported by calcein staining experiments (e.g. Tambutté et al., 2012). The relative contributions of the transcellular and paracellular pathways to the calcification process are, however, unknown. The active removal of protons by the calicoblastic epithelium increases the saturation state in the calcifying fluid, making the conditions for the crystallization of aragonite more favourable. Calcification rates of corals are among the highest of all animals (Cohen and McConnaughey, 2003). The rapid calcification rates and the discovery of organic molecules that are incorporated into the coral skeleton led to the hypothesis that organic molecules act as an organic matrix that initiates the crystallization of the coral skeleton, thus catalyzing coral calcification (Allemand et al., 1998; Clode and Marshall, 2002; Cuif and Dauphin, 2005; Helman et al., 2008). A structuring effect, however, has never been shown for these organic molecules and the catalyzation has not yet been quantified. Organic molecules are incorporated in banding layers within the skeleton (Cuif and Dauphin, 2005) as shown by acridine orange staining experiments (Stolarski, 2003). But these banding structures have also been found in inorganically precipitated aragonite that did not incorporate any organic molecules (Holcomb et al., 2009).

The calicoblastic epithelium cells excrete a number of molecules into the subcalicoblastic space, including Carbonic Anhydrase (Moya et al., 2008). Carbonic Anhydrase (CA) catalyzes the otherwise very slow reaction: $\mathrm{CO}_{2}+$ $\mathrm{H}_{2} \mathrm{O} \rightleftharpoons \mathrm{HCO}_{3}^{-}+\mathrm{H}^{+}$(Sueltemeyer et al., 1993) and might support calcification by increasing the supply of bicarbonate and subsequently carbonate ions to the calcifying fluid.

Coral calcification rates are enhanced when corals are exposed to light due to the additional energy provided by photosynthesizing symbionts (Chalker and Taylor, 1975; Chalker, 1981; Marubini et al., 2001; Moya et al., 2006). Aragonite precipitation by corals therefore cannot be treated exclusively as a physico-chemical process (Burton and Walter, 1990). Food availability, changes in temperature and other environmental factors can substantially alter coral growth (Szmant-Froelich and Pilson, 1980; Kleypas et al., 1999; Lough and Barnes, 2000). The calcification response to changes in the carbonate chemistry of the growth environment due to $p \mathrm{CO}_{2}$ manipulations appears ambiguous (Ries et al., 2009), although the majority of observations show a reduction of coral calcification with increasing $p \mathrm{CO}_{2}$ (e.g. Gattuso et al., 1998; Langdon, 2002; Marubini et al., 2008; Cohen and Holcomb, 2009; McCulloch et al., 2012).

Despite several decades of coral research, the physiological control of the calcifying fluid by scleractinian hermatypic corals remains still unclear (Tambutté et al., 2011). If the calcifying fluid is metabolically controlled by the coral polyp and differs substantially from the growth medium, how and why should precipitation and dissolution of calcium carbonate in the calcifying fluid be related to external changes in seawater chemistry? To address this question, we developed 
a mathematical model of coral polyp calcification that computes the kinetic reactions of the carbonate chemistry in four different compartments: the seawater, the polyp tissue, the coelenteron, and the calcifying fluid (as inspired by Tambutte et al., 1996). The model is constrained by the microsensor experiments of Al-Horani et al. (2003), which provides time series of calcium concentrations and $\mathrm{pH}$ in the calcifying fluid under light-dark conditions and represents to date a unique and most valuable dataset (Cohen and Holcomb, 2009). We used the model to investigate (1) the temporal dynamics of the carbonate system in the different model compartments, (2) the physiological mechanisms controlling the calcifying fluid, and (3) the responses of polyp calcification to ocean acidification by perturbing $\mathrm{CO}_{2}$ concentrations in the growth medium.

\section{Methods}

\subsection{Model description}

We developed a box model for a coral polyp that comprises the growth medium (seawater), the stomach room (coelenteron), the actual body (tissue), and the medium in the subcalicoblastic layer (calcifying fluid) as separate compartments (Fig. 1). This setup was inspired by the work of Tambutte et al. (1996), in which equivalent compartments were identified with kinetic analyses of calcium transport. The model resolves the full kinetic reactions of the carbonate system according to Zeebe and Wolf-Gladrow (2001). In each compartment, the following state variables are considered: dissolved carbon dioxide $\left(\mathrm{CO}_{2}\right)$, bicarbonate $\left(\mathrm{HCO}_{3}^{-}\right)$, carbonate $\left(\mathrm{CO}_{3}^{2-}\right)$, protons $\left(\mathrm{H}^{+}\right)$, hydroxide ions $\left(\mathrm{OH}^{-}\right)$, boric acid $\left(\mathrm{B}(\mathrm{OH})_{3}\right)$, borate $\left(\mathrm{B}(\mathrm{OH})_{4}^{-}\right)$, and calcium ions $\left(\mathrm{Ca}^{2+}\right)$.

Fluxes across the boundary layers connect the pools of the various chemical components between the different compartments, driving the dynamics of the full kinetic model (Fig. 2). Since the mouth of the polyp opens the coelenteron to the seawater and given that the oral epithelial layers can be assumed to be permeable to ions via a paracellular pathway (Benazet-Tambutte et al., 1996), we define an advective flux that exchanges all state variables between the coelenteron and the seawater at a constant exchange rate. The seawater compartment is connected to an overlying atmosphere via the air-sea gas-exchange of $\mathrm{CO}_{2}$ (Wanninkhof, 1992). Atmospheric $\mathrm{CO}_{2}$ concentrations, ambient temperature, and seawater salinity, are used as external forcing. $\mathrm{CO}_{2}$ is assumed to freely diffuse from the seawater, the coelenteron, and the calcifying fluid into the polyp tissue and out again (Fig. 2, processes 4 and 7), depending on the concentration gradient and the diffusivity of $\mathrm{CO}_{2}$ over eukaryotic cell membranes (Sueltemeyer and Rinast, 1996). Respiration and photosynthesis are considered as source and sink of $\mathrm{CO}_{2}$ within the polyp tissue (Fig. 2, process 9).

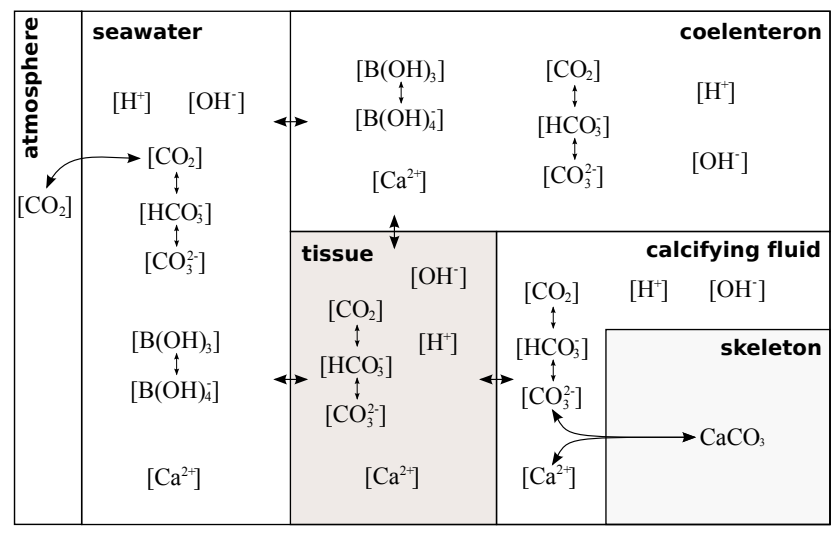

Fig. 1. Schematic of the coral polyp model. Four boxes are considered in the model (seawater, coelenteron, tissue, calcifying fluid), which are interconnected via fluxes over the boundary layers. The seawater compartment is connected to an atmosphere with predefined $p \mathrm{CO}_{2}$. Precipitation of the coral skeleton (calcification) occurs in the calcifying fluid. State variables and fluxes are described in the text.

The passage of charged ions over the lipid bilayer of cell membranes can only be achieved via specific transport proteins or channels, both observed in coral cells (Zoccola et al., 1999, 2004). Calcium transport from the tissue to the calcifying fluid occurs against a concentration gradient and is assumed to be mediated by an active $\mathrm{Ca}^{2+}-\mathrm{H}^{+}$antiporter (Ca-ATPase, Ip et al., 1991; Zoccola et al., 2004). In our model, the Ca-ATPase is parameterized with simple Michaelis-Menten kinetics as a function of calcium concentration in the cytoplasm of the coral tissue, and is assumed to transport two protons for each calcium ion to assure charge balance (Fig. 2, process 5). The passage of calcium into the coral tissue is likely driven by the concentration gradient of calcium across the plasma membrane (Gussone et al., 2006). This gradient can be utilized by a calcium channel (Zoccola et al., 1999; Carafoli, 2002). Due to the requirement of calcium homeostasis in eukaryotic cells (Carafoli, 1987), we assume that the entry of calcium into the coral tissue equals active calcium transport into the calcifying fluid. A bicarbonate transporter (co-transport of $\mathrm{HCO}_{3}^{-}$and $\mathrm{H}^{+}$) has been proposed by Furla et al. (2000) and appears to be responsible for active carbon uptake from the seawater and the coelenteron into the tissue (Fig. 2, process 3), and for transport from the tissue into the calcifying fluid (Fig. 2, process 6). The bicarbonate transporter is parameterized with Michaelis-Menten kinetics, with influx into the tissue assumed to equal efflux. The activity of the Ca-ATPase removes protons from the calcifying fluid. To avoid protons from accumulating in the coral tissue, they are removed and eventually released into seawater (Allemand et al., 2004). Since the gastric cavity of corals has a lower $\mathrm{pH}$ than the external seawater and since the $\mathrm{pH}$ is known to decrease in the dark (Agostini et al., 2012), we 


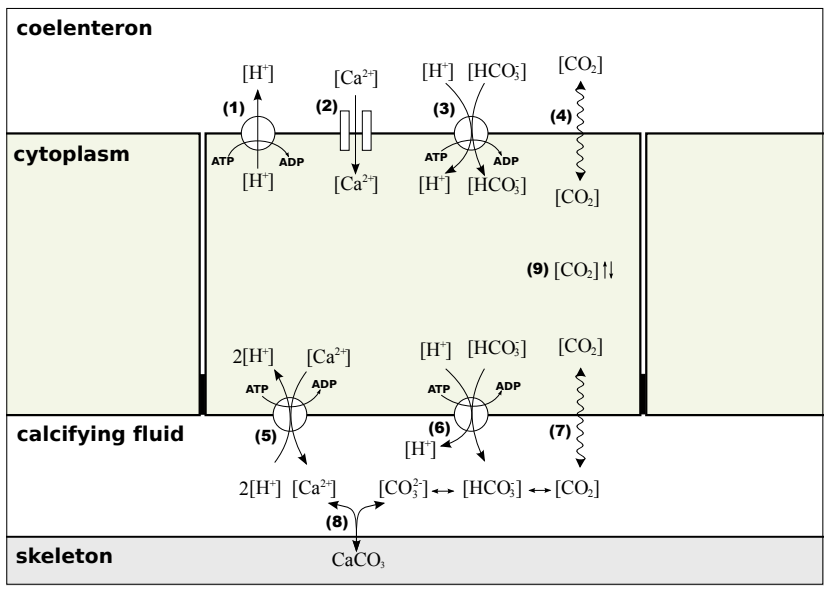

Fig. 2. Processes considered in the model. (1) active proton pump (Allemand et al., 2004), (2) passive calcium channel (Zoccola et al., 1999; Allemand et al., 2004), (3) active uptake of bicarbonate (Furla et al., 2000), (4) $\mathrm{CO}_{2}$ diffusion (Sueltemeyer and Rinast, 1996), (5) active calcium transport (Ip et al., 1991; Zoccola et al., 2004), (6) active bicarbonate transport (Furla et al., 2000), (7) $\mathrm{CO}_{2}$ diffusion (Sueltemeyer and Rinast, 1996), (8) aragonite precipitation (Burton and Walter, 1990), (9) photosynthesis and respiration (Al-Horani et al., 2003).

assume a proton pump that releases protons from the tissue into the coelenteron in the dark (Fig. 2, process 1).

Besides the transcellular transport of ions into the calcifying fluid, a paracellular pathway has been proposed in the calicoblastic epithelium (Tambutté et al., 2011, 2012). The paracellular passage would indicate free diffusion of ions or advection of seawater through the intercellular space and passage of the tight junctions of the calicoblastic epithelium. This pathway could also introduce magnesium ions and phosphate to the calcifying fluid with the effect of reducing the physiological control of the coral polyp on the chemical composition of the calcifying fluid. Given the uncertainties concerning the existence of the paracellular pathway, or the extent to which it contributes to exchange ions, our model includes only the transcellular pathway of calcium and bicarbonate.

Different theories exist about the biological control of coral calcification (reviewed in Tambutté et al., 2011). The occurrence of organic molecules in the banded structures of coral skeletons (Stolarski, 2003) suggests that these molecules could be somehow involved in the calcification process (Allemand et al., 1998; Clode and Marshall, 2002). The hypothesis of an organic matrix controlling the calcification process, however, has been questioned by Holcomb et al. (2009) and the potential role of an organic matrix as catalyser of aragonite precipitation has not been quantified yet. These uncertainties impede the development of a meaningful parameterization for calcification as a mechanism controlled by an organic matrix. The crystallization of $\mathrm{CaCO}_{3}$ in aqueous solutions requires supersaturation with respect to a certain mineral phase (Burton and Walter, 1990; Lasaga, 1998; Zeebe and Wolf-Gladrow, 2001) and the precipitation of aragonite is generally well described by the equation $k_{p} \cdot(\Omega-1)^{n}$ (following Burton and Walter, 1990). We therefore focus on the "bio-inorganic" model of coral calcification in which (1) the incorporation of organic molecules into the coral skeleton is assumed to be a by-product of rapid crystal growth (Tambutté et al., 2011) and (2) the crystallization follows classical precipitation-dissolution kinetics.

Carbonic anhydrase is produced by the calicoblastic epithelium cells of Stylophora pistillata (Moya et al., 2008). However, the concentration of this enzyme and its activity in the calcifying fluid is not known. For the sake of simplicity, carbonic anhydrase is not considered in our model. All model equations are reported in the Appendix. The model is coded in the computer language python.

\subsection{Model runs}

Our model is constrained with observations collected by microsensor experiments (Al-Horani et al., 2003), comprising calcium ion concentrations and $\mathrm{pH}$ measured at the polyp surface, in the coelenteron and in the calcifying fluid beneath the coral tissue. In these experiments, the time evolution of calcium ion concentrations and $\mathrm{pH}$ was measured during coral exposure to alternating periods of light and dark. Due to limitations in the methodology, the experiments were not performed simultaneously and thus the data are from runs carried out at different times and for different time intervals. In our model, however, all concentrations are determined simultaneously, thus allowing investigations of direct interactions and interdependencies of state variables in the various model compartments. The model is set up to obtain the best representation of calcium ion concentrations in the calcifying fluid (Fig. 3d), as this is one of the most relevant constituents of coral calcification.

The simulation is run for 1260 seconds with a time step of $6 \times 10^{-4}$ s. In analogy to Al-Horani et al. (2003, Fig. 2), light periods are from 0 to $420 \mathrm{~s}$ and from 840 to $1260 \mathrm{~s}$ and the dark period is from 420 to $840 \mathrm{~s}$. Photosynthesis in the light consumes $\mathrm{CO}_{2}$ in the coral tissue and provides metabolic energy for active ion transport. In the dark, respiration increases $\mathrm{CO}_{2}$ in the coral tissue.

Al-Horani et al. (2003) used the coral Galaxea fascicularis, a species with relatively large polyps. The sizes of the compartments required by the model are obtained by assuming spherical geometry of the polyp with densest sphere packing of polyps within the colony. The diameter of a $G$. fascicularis polyp is approximately $8.2 \mathrm{~mm}$ (Leuzinger et al., 2003). The thickness of the coral tissue is assumed to be $3.0 \mathrm{~mm}$. The resulting compartment sizes are given in Table 2. The volume of seawater was set to $1 \mathrm{~m}^{3}$. Consistent with the microsensor experiments (Al-Horani et al., 2003), seawater temperature was set to $20.5^{\circ} \mathrm{C}$ and salinity was set to 40 psu. 
Table 1. Initial concentrations of state variables.

\begin{tabular}{llllll}
\hline State variable & Seawater & Coelenteron & Tissue & Calcifying fluid & Unit \\
\hline $\mathrm{CO}_{2}$ & $9.631 \times 10^{-6}$ & $16.051 \times 10^{-6}$ & $8.813 \times 10^{-6}$ & $0.253 \times 10^{-6}$ & $\mathrm{~mol} \mathrm{~kg}^{-1}$ \\
$\mathrm{HCO}_{3}^{-}$ & $2055.9 \times 10^{-6}$ & $2162.0 \times 10^{-6}$ & $188.1 \times 10^{-6}$ & $458.7 \times 10^{-6}$ & $\mathrm{~mol} \mathrm{~kg}^{-1}$ \\
$\mathrm{CO}_{3}^{2-}$ & $334.46 \times 10^{-6}$ & $221.92 \times 10^{-6}$ & $3.06 \times 10^{-6}$ & $101.46 \times 10^{-6}$ & $\mathrm{~mol} \mathrm{~kg}^{-1}$ \\
$\mathrm{H}^{+}$ & $6.310 \times 10^{-9}$ & $1.0 \times 10^{-8}$ & $6.310 \times 10^{-8}$ & $1.318 \times 10^{-9}$ & $\mathrm{~mol} \mathrm{~kg}^{-1}$ \\
$\mathrm{OH}^{-}$ & $6.899 \times 10^{-6}$ & $4.353 \times 10^{-6}$ & $6.899 \times 10^{-7}$ & $3.302 \times 10^{-5}$ & $\mathrm{~mol} \mathrm{~kg}^{-1}$ \\
$\mathrm{H}_{2} \mathrm{O}$ & 53.6 & 53.6 & 53.6 & 53.6 & $\mathrm{~mol} \mathrm{~kg}^{-1}$ \\
$\mathrm{~B}(\mathrm{OH})_{4}^{-}$ & $129.92 \times 10^{-6}$ & $91.173 \times 10^{-6}$ & $17.233 \times 10^{-6}$ & $305.53 \times 10^{-6}$ & $\mathrm{~mol} \mathrm{~kg}^{-1}$ \\
$\mathrm{~B}(\mathrm{OH})_{3}$ & $345.232 \times 10^{-6}$ & $383.979 \times 10^{-6}$ & $457.919 \times 10^{-6}$ & $169.622 \times 10^{-6}$ & $\mathrm{~mol} \mathrm{~kg}^{-1}$ \\
$\mathrm{Ca}^{2+}$ & $10.0 \times 10^{-3}$ & $10.0 \times 10^{-3}$ & $0.5 \times 10^{-3}$ & $10.65 \times 10^{-3}$ & $\mathrm{~mol} \mathrm{~kg}^{-1}$ \\
$\mathrm{CaCO}_{3}$ & - & - & - & $0.1 \times 10^{-6}$ & $\mathrm{~mol} \mathrm{~kg}^{-1}$ \\
\hline
\end{tabular}

\subsection{Model scenarios}

After defining a set of parameter values (Table 2) and initial conditions (Table 1) with which the model adequately represents the observations, we repeat the model simulations for different atmospheric $p \mathrm{CO}_{2}$ to determine the effect of changing seawater chemistry on the calcification rate of the simulated polyp. The carbonate chemistry in the seawater compartment is initialized to be in equilibrium with the atmosphere at $\mathrm{CO}_{2}$ partial pressures of 280, 380, 700, and 1000 ppmv (Table 3). The initial values of the other state variables and parameters are set according to the reference run (Tables 1 and 2).

\section{Results}

Even though the model resolves the time evolution of the full set of state variables, i.e. all components of the carbonate system, we sum up carbon dioxide, bicarbonate, and carbonate and consider total dissolved inorganic carbon (DIC) to simplify the analysis of the model results. Bicarbonate, carbonate, hydroxide ions, protons and borate are combined to calculate total alkalinity (TA) in all model compartments (WolfGladrow et al., 2007). pH is determined from proton concentrations. As $\mathrm{pH}$ data were obtained from experiments with slightly different time intervals than the experiments carried out to obtain calcium ion concentrations, we shifted the $\mathrm{pH}$ data on the time axis to match the switches in light conditions in the simulation (Fig. 4c and d).

\subsection{Calcifying fluid}

Four processes influence state variables in the calcifying fluid: (1) diffusion of $\mathrm{CO}_{2}$, (2) $\mathrm{HCO}_{3}^{-}$-transport, (3) $\mathrm{Ca}^{2+}$ transport, and (4) calcification (mineralization) (see also Fig. 2, processes 5-8). Active transport of calcium from the tissue increases calcium concentrations in the calcifying fluid during light exposure (Fig. 3d). Calcium transport concurrently removes protons from the calcifying fluid, thus also

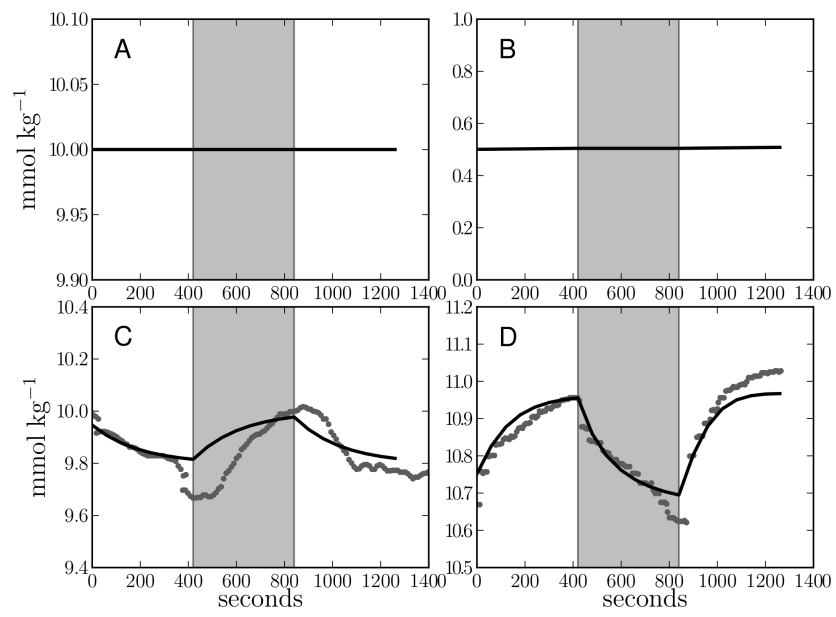

Fig. 3. Simulated calcium ion concentrations over time (black lines) in the four model compartments $(\mathbf{A}=$ seawater; $\mathbf{B}=$ tissue; $\mathbf{C}=$ coelenteron $\mathbf{D}=$ calcifying fluid). The observations (grey dots) are from the microsensor studies of Al Horani et al. (2003). Light periods range from 0 to $420 \mathrm{~s}$ and from 840 to $1260 \mathrm{~s}$. The dark period is between 420 and $840 \mathrm{~s}$.

increasing $\mathrm{pH}$ and total alkalinity (Figs. 4 and 6d). In the dark, calcium transport is stopped and calcium ions are removed from the calcifying fluid by aragonite precipitation. The mineralization of aragonite also removes carbonate from the calcifying fluid, thus decreasing total alkalinity and DIC (Fig. 6d). However, since $\mathrm{CO}_{2}$ produced in the tissue by dark respiration diffuses into the calcifying fluid, a net increase in total DIC is observed in this compartment during the dark phase (Fig. 5d).

The transport of bicarbonate into the calcifying fluid increases total DIC in the light phase. $\mathrm{CO}_{2}$ diffusion, however, works in both directions, from the calcifying fluid into the polyp tissue and vice versa. In the light, photosynthesis fixes $\mathrm{CO}_{2}$ in the polyp tissue and creates a gradient that draws $\mathrm{CO}_{2}$ from the calcifying fluid into the polyp tissue. In the dark, respiration reverses this gradient and $\mathrm{CO}_{2}$ diffusion resupplies DIC to the calcifying fluid despite the absence of active 

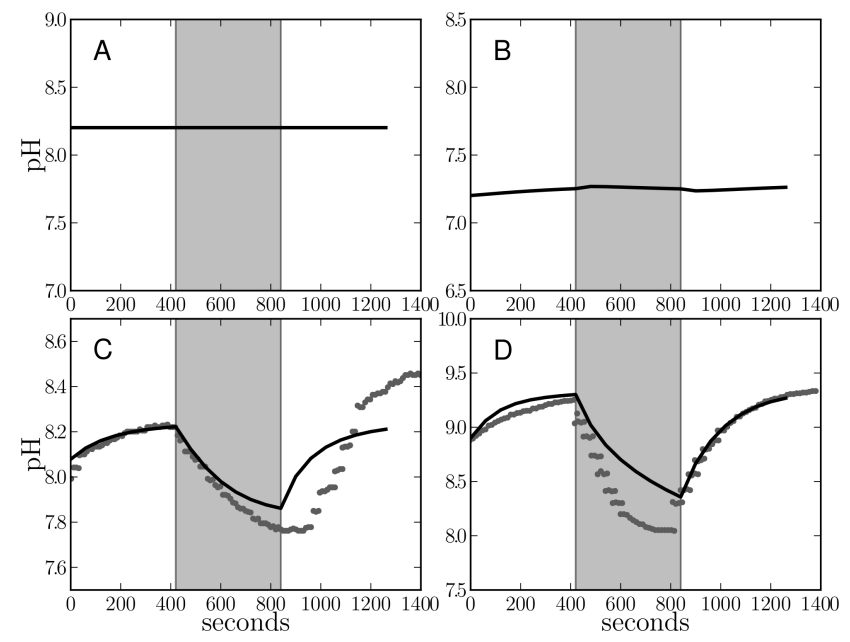

Fig. 4. Simulated $\mathrm{pH}$ over time (black lines) in the four model compartments $(\mathbf{A}=$ seawater $\mathbf{B}=$ tissue $; \mathbf{C}=$ coelenteron $\mathbf{D}=$ calcifying fluid). The observations (grey dots) are from the microsensor studies of Al Horani et al. (2003). Light periods range from 0 to $420 \mathrm{~s}$ and from 840 to $1260 \mathrm{~s}$. The dark period is between 420 and $840 \mathrm{~s}$.

bicarbonate transport. Since diffusion is driven by a concentration gradient, the gradual changes in $\mathrm{CO}_{2}$ concentrations produce a time lag or a gradual shift in diffusion rates after the light switches. In addition to the calcium-proton antitransport, the $\mathrm{pH}$ in the calcifying fluid also responds to $\mathrm{CO}_{2}$ diffusion by increasing $\mathrm{pH}$ in the light while decreasing it in the dark.

\subsection{Tissue}

To assure calcium homeostasis in the cytoplasm (Carafoli, 1987), the rate of calcium uptake by the coral tissue is assumed to be the same order of magnitude as the transport rate of calcium from the tissue to the calcifying fluid. As a consequence, the intracellular calcium concentration remains stable at about $0.5 \mathrm{mM}$ (Fig. 3b). For every calcium ion exported, alkalinity is reduced in the cytoplasm due to the import of two protons. However, since protons are in turn exported into the coelenteron, total alkalinity remains relatively stable in the tissue throughout the simulation period (Fig. 6b). The $\mathrm{pH}$ in the coral tissue slightly increases from around 7.2 to about 7.3 in the light period due to photosynthetic consumption of $\mathrm{CO}_{2}$ (Fig. 4b). In the dark, respiratory $\mathrm{CO}_{2}$ production leads to a decrease in tissue $\mathrm{pH}$. The observed range in coral tissue $\mathrm{pH}$ is in agreement with $\mathrm{pH}$ imaging of calicoblastic epithelium cells (Venn et al., 2009). Despite influencing the $\mathrm{pH}$ in the coral tissue, the addition (or removal) of $\mathrm{CO}_{2}$ does not affect total alkalinity. The respiratory release and photosynthetic consumption of $\mathrm{CO}_{2}$, however, can be noticed in the small DIC changes occurring in the coral tissue (Fig. 5b).

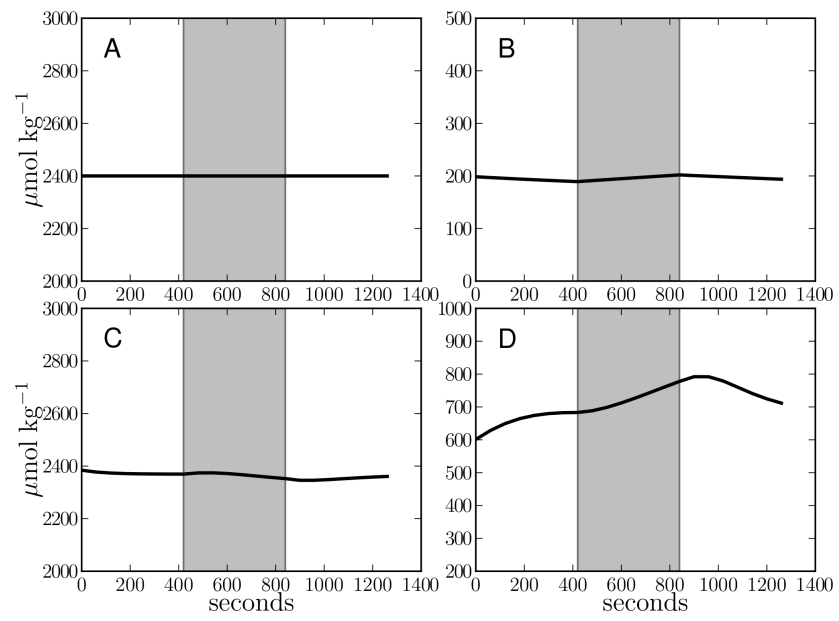

Fig. 5. Simulated DIC concentrations over time (black lines) in the four model compartments $(\mathbf{A}=$ seawater; $\mathbf{B}=$ tissue; $\mathbf{C}=$ coelenteron $; \mathbf{D}=$ calcifying fluid). Light periods range from 0 to $420 \mathrm{~s}$ and from 840 to $1260 \mathrm{~s}$. The dark period is between 420 and $840 \mathrm{~s}$.

\subsection{Seawater}

In the model, the metabolic activity of the coral has hardly any influence on seawater composition because the volume of the seawater compartment is much larger than the polyp and the fluxes are negligible compared to the large reservoir of the growth medium. Concentrations of state variables in the seawater compartment therefore do not change over time (Figs. 3-6a).

\subsection{Coelenteron}

The uptake of calcium during the light period decreases calcium ion concentrations in the coelenteron (Fig. 3c). During dark phases, calcium is resupplied via advective water exchange between the coelenteron and the seawater compartments so that its concentration is restored towards background values $\left(10 \mathrm{mmol} \mathrm{kg}^{-1}\right)$. The uptake of calcium by the coral tissue is simulated with a diffusive influx over a calcium channel (Fig. 2, process 2). Calcium uptake from the coelenteron therefore does not decrease the $\mathrm{pH}$ as one might expect because of the calcium-proton anti-transport. The coelenteron $\mathrm{pH}$ increases in the light due to the decrease of $\mathrm{CO}_{2}$ (Figs. $4 \mathrm{c}$ and $5 \mathrm{c}$ ), the reason being photosynthetic carbon fixation and successive $\mathrm{CO}_{2}$ diffusion from the coelenteron into the tissue. Respiration and proton transport from the tissue into the coelenteron decrease $\mathrm{pH}$ and total alkalinity in the dark (Fig. 6c).

\subsection{Calcification over time}

The light-dependent metabolic activity of the coral polyp (i.e. the active transport of calcium and bicarbonate, the removal of protons, and the suction of $\mathrm{CO}_{2}$ to the site of 
Table 2. Model parameters.

\begin{tabular}{|c|c|c|c|}
\hline Variable & Definition & Value and unit & Source \\
\hline$\omega$ & exchange rate of advective transport & $0.3 \min ^{-1}$ & estimated \\
\hline $\mathrm{D}_{\mathrm{CO}_{2}}$ & diffusion coefficient for $\mathrm{CO}_{2}$ & $2.8 \times 10^{-3} \mathrm{~cm} \mathrm{~s}^{-1}$ & Sueltemeyer and Rinast (1996) \\
\hline$V_{\mathrm{HCO}_{3 \text { (sea) }}}$ & maximum uptake rate for bicarbonate (sea-tiss) & 42.2 pmol polyp $^{-1} \mathrm{~min}^{-1}$ & estimated \\
\hline$V_{\mathrm{HCO}_{3(\text { coel })}}$ & maximum uptake rate for bicarbonate (coel-tiss) & 42.2 pmol polyp $^{-1} \mathrm{~min}^{-1}$ & estimated \\
\hline$V_{\mathrm{HCO}_{3} \text { (tiss) }}$ & maximum transport rate for bicarbonate (tiss-cali) & 42.2 pmol polyp $^{-1} \mathrm{~min}^{-1}$ & estimated \\
\hline$k_{\mathrm{HCO}_{3}}$ & half-saturation constant bicarbonate transport & $1.0 \mathrm{mmol} \mathrm{m}^{-3}$ & estimated \\
\hline$P_{\mathrm{Ca}}$ & permeability of calcium channel & $4.0 \times 10^{-6} \mathrm{~cm} \mathrm{~s}^{-1}$ & estimated \\
\hline$V_{\mathrm{Ca}}($ tiss) & maximum transport rate for calcium (tiss-cali) & $438.75 \mathrm{pmol} \mathrm{Ca} \mathrm{polyp}^{-1} \min ^{-1}$ & estimated \\
\hline$k_{\mathrm{Ca}}$ & half-saturation constant of calcium transport & $1.0 \mathrm{mmol}^{-3}$ & Araki and González (1998) \\
\hline$H_{\text {pump }}$ & transport rate of proton pump per polyp & $9.4 \mathrm{pmol} \mathrm{s}^{-1}$ & estimated \\
\hline$C_{\text {phot }}$ & net photosynthesis rate per polyp & $40 \mu \mathrm{mol} \mathrm{m}{ }^{-3} \mathrm{~s}^{-1}$ & estimated \\
\hline$C_{\text {resp }}$ & dark respiration rate per polyp & $20 \mu \mathrm{mol} \mathrm{m}{ }^{-3} \mathrm{~s}^{-1}$ & estimated \\
\hline $\mathcal{S}$ & light switch & 0 or 1 (dimensionless) & defined \\
\hline$k_{p}$ & reaction rate for mineralization & $1.61 \mu \mathrm{mol} \mathrm{m}{ }^{-2} \mathrm{~h}^{-1}$ & Burton and Walter (1990) \\
\hline$n$ & empirical reaction order & 1.63 (dimensionless) & Burton and Walter (1990) \\
\hline Vol $_{\text {sea }}$ & Volume of seawater compartment & $1.0 \mathrm{~m}^{3}$ & estimated \\
\hline Vol $_{\text {coel }}$ & Volume of coelenteron & $5.575 \times 10^{-9} \mathrm{~m}^{3}$ & estimated \\
\hline $\mathrm{Vol}_{\text {tiss }}$ & Volume of tissue compartment per polyp & $355.933 \times 10^{-9} \mathrm{~m}^{3}$ & estimated \\
\hline $\mathrm{Vol}_{\mathrm{calc}}$ & Volume of calcifying fluid per polyp & $1.110 \times 10^{-9} \mathrm{~m}^{3}$ & estimated \\
\hline
\end{tabular}

Table 3. Initial conditions of state variables for $p \mathrm{CO}_{2}$ scenarios at $\mathrm{TA}=2300 \mu \mathrm{mol} \mathrm{kg}^{-1}$.

\begin{tabular}{llllll}
\hline State variable & $280 \mathrm{ppmv}$ & $380 \mathrm{ppmv}$ & $700 \mathrm{ppmv}$ & $1000 \mathrm{ppmv}$ & Unit \\
\hline $\mathrm{CO}_{2 \text { (sea) }}$ & $7.502 \times 10^{-6}$ & $10.181 \times 10^{-6}$ & $18.755 \times 10^{-6}$ & $26.793 \times 10^{-6}$ & $\mathrm{~mol} \mathrm{~kg}^{-1}$ \\
$\mathrm{HCO}_{3 \text { (sea) }}$ & $1.599 \times 10^{-3}$ & $1.711 \times 10^{-3}$ & $1.905 \times 10^{-3}$ & $1.996 \times 10^{-3}$ & $\mathrm{~mol} \mathrm{~kg}^{-1}$ \\
$\mathrm{CO}_{3 \text { (sea) }}^{2-4}$ & $2.791 \times 10^{-4}$ & $2.353 \times 10^{-4}$ & $1.583 \times 10^{-4}$ & $1.218 \times 10^{-4}$ & $\mathrm{~mol} \mathrm{~kg}^{-1}$ \\
$\mathrm{H}_{\text {(sea) }}^{+}$ & $6.973 \times 10^{-9}$ & $8.847 \times 10^{-9}$ & $14.639 \times 10^{-9}$ & $19.948 \times 10^{-9}$ & $\mathrm{~mol} \mathrm{~kg}^{-1}$ \\
$\mathrm{OH}_{(\text {sea) }}^{-}$ & $6.243 \times 10^{-6}$ & $4.920 \times 10^{-6}$ & $2.974 \times 10^{-6}$ & $2.182 \times 10^{-6}$ & $\mathrm{~mol} \mathrm{~kg}^{-1}$ \\
$\mathrm{~B}(\mathrm{OH})_{3 \text { (sea) }}$ & $3.421 \times 10^{-4}$ & $3.637 \times 10^{-4}$ & $4.009 \times 10^{-4}$ & $4.183 \times 10^{-4}$ & $\mathrm{~mol} \mathrm{~kg}^{-1}$ \\
$\mathrm{~B}(\mathrm{OH})_{4(\text { sea })}^{-4}$ & $1.331 \times 10^{-4}$ & $1.115 \times 10^{-4}$ & $7.427 \times 10^{-5}$ & $5.686 \times 10^{-5}$ & $\mathrm{~mol} \mathrm{~kg}^{-1}$ \\
\hline
\end{tabular}

photosynthesis) increases the concentrations of calcium and carbonate ions in the calcifying fluid, thus increasing the saturation state of calcium carbonate. In the model, the precipitation and dissolution of aragonite only depend on the aragonite saturation state in the calcifying fluid (Eq. A12). As shown in Fig. 7, the increase of the calcification rate during light exposure is the result of the active metabolic regulation of the ion composition in the calcifying fluid. Only when light is switched off and the ion transport mechanism is inactive, mineralization of aragonite depletes calcium and carbonate and the calcifying fluid approaches equilibrium with the mineral phase (Fig. 7). Note that calcification does not stop entirely in the dark. $\mathrm{CO}_{2}$ diffusion, due to polyp respiration in the dark, acts as a source of DIC to the calcifying fluid, thus never allowing the calcifying fluid to reach the equilibrium with the mineral phase. Calcification rates vary between 0 and $2 \mathrm{mmol} \mathrm{Ca} \mathrm{m}^{-2} \mathrm{~d}^{-1}$ (Fig. 7).
Calcification is limited in the light by the active transport rates of calcium and bicarbonate and by the consequent increase in aragonite precipitation, which leads to a quasisteady-state between transport and precipitation that determines maximum concentrations of calcium and carbonate in the calcifying fluid. While aragonite precipitation follows passively the increase in calcium and carbonate concentrations, the concentrations of calcium and carbonate in the calcifying fluid depend only on active transport rates and $\mathrm{CO}_{2}$ diffusion.

\subsection{Calcification over $p \mathrm{CO}_{2}$}

Since one of the aims of our study is to investigate how changes in seawater carbonate chemistry affect coral polyp calcification, we performed $p \mathrm{CO}_{2}$ perturbation experiments at atmospheric $p \mathrm{CO}_{2}$ levels of $280,380,700$, and 

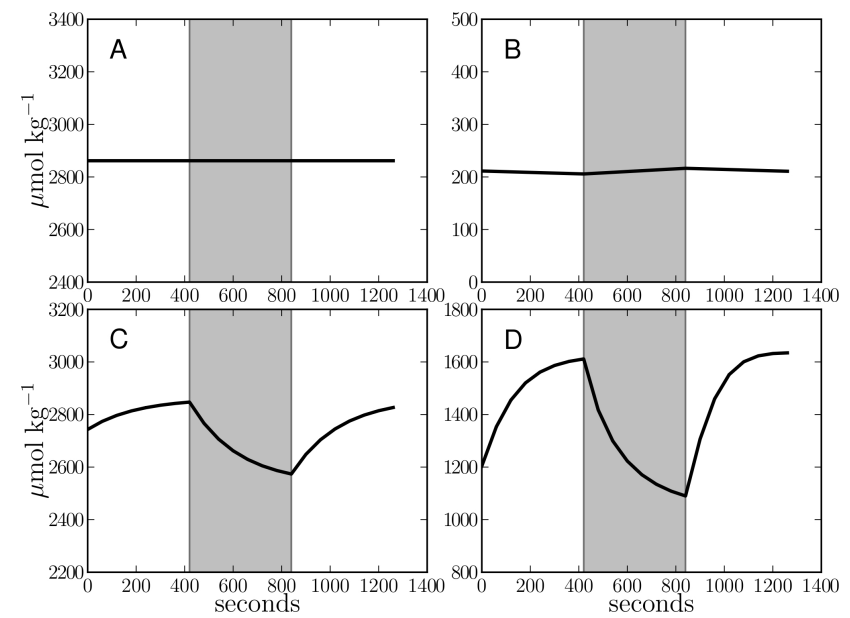

Fig. 6. Simulated total alkalinity over time (black lines) in the four model compartments $(\mathbf{A}=$ seawater; $\mathbf{B}=$ tissue; $\mathbf{C}=$ coelenteron; $\mathbf{D}=$ calcifying fluid). Light periods range from 0 to $420 \mathrm{~s}$ and from 840 to $1260 \mathrm{~s}$. The dark period is between 420 and $840 \mathrm{~s}$.

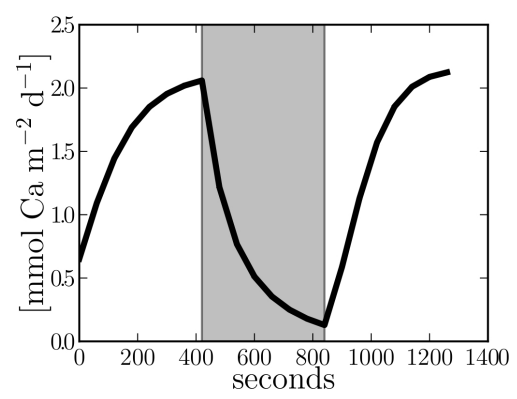

Fig. 7. Net calcification rate over time. Light periods range from 0 to $420 \mathrm{~s}$ and from 840 to $1260 \mathrm{~s}$. The dark period is between 420 and $840 \mathrm{~s}$.

1000 ppmv. For each scenario, we run the model as described in the reference run (Fig. 7) and calculate the average calcification rates over the whole simulation period. Average coral polyp calcification decreases with increasing $p \mathrm{CO}_{2}$ in the growth medium (Fig. 8) despite the strong metabolic control of the calcifying fluid. These results are in accordance with other experimental studies showing decreasing calcification rates with increasing $p \mathrm{CO}_{2}$ (e.g. Gattuso et al., 1998; Marubini et al., 2008; Holcomb et al., 2010; McCulloch et al., 2012).

In the model, the calcifying fluid is not directly connected to seawater and we assume no active transport of $\mathrm{CO}_{3}^{2-}$. Hence, the decrease of polyp calcification with increasing $p \mathrm{CO}_{2}$ cannot be explained by the decrease of carbonate ion concentrations (i.e. lower saturation state) in the seawater compartment. The simulated saturation state in the calcifying fluid, however, decreases with increasing $p \mathrm{CO}_{2}$. The relative decrease in carbonate ion concentrations in the calcifying fluid is caused by elevated diffusion of $\mathrm{CO}_{2}$ from seawater through the coral tissue into the calcifying fluid.

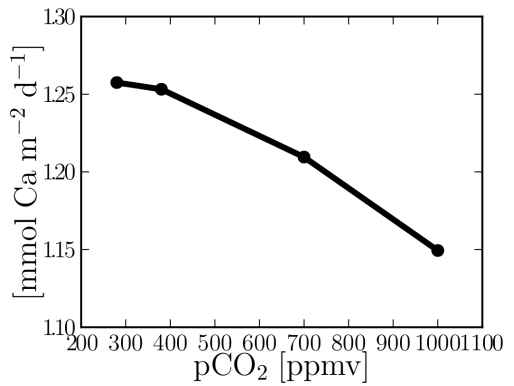

Fig. 8. Effect of changing seawater $p \mathrm{CO}_{2}$ on the average coral calcification rate.

\section{Discussion}

\subsection{Sensitivity of coral calcification to ocean acidification}

This study addresses the questions of how and why coral calcification is influenced by $p \mathrm{CO}_{2}$ changes in seawater. The answers are not straightforward because: (1) the calcifying fluid is separated from seawater by the polyp tissue, and (2) the ion composition of the calcifying fluid is metabolically controlled. Our model, however, shows a decline in coral polyp calcification with increasing seawater $p \mathrm{CO}_{2}$ (Fig. 8), as also observed in several other experimental studies (Gattuso et al., 1998; Marubini et al., 2008; Holcomb et al., 2010; McCulloch et al., 2012). This result, together with the good representation of the short-term lab-experiments of $\mathrm{Al}$ Horani et al. (2003), suggests that the model is based on reasonable assumptions and is able to capture the most relevant processes involved in coral calcification.

As explained in the methods section, the paracellular pathway for ion exchange between the seawater and the calcifying fluid has not been considered in this study. The connection between the calcifying fluid and the growth medium is realized via free diffusion of $\mathrm{CO}_{2}$ over cell membranes and through the cells of the polyp tissue. In addition to $\mathrm{CO}_{2}$ diffusion, we considered a bicarbonate transporter from the seawater into the tissue and from the tissue into the calcifying fluid, as proposed by Furla et al. (2000). With rising atmospheric $p \mathrm{CO}_{2}$, more $\mathrm{CO}_{2}$ diffuses from the growth medium to the calcification site and bicarbonate transport increases slightly. When calcium transport to the calcification site is fixed in the different scenarios, the increased supply of $\mathrm{CO}_{2}$ and $\mathrm{HCO}_{3}^{-}$changes the carbonate chemistry in the calcifying fluid and decreases the concentration of carbonate ions, ultimately altering the overall calcification rate (Fig. 8).

The basic physiological mechanisms and pathways considered in the model are based on first principles and chemical reaction kinetics. Therefore, relative to the very short time scales considered, the model reproduces the experiments by Al-Horani et al. (2003) with good accuracy. The inorganic carbonate chemistry is not affected by major uncertainties 
(Zeebe and Wolf-Gladrow, 2001; Riebesell et al., 2009) and even the mechanisms of active calcium transport into the calcifying fluid are relatively well understood (Ip et al., 1991; MacLennan et al., 1997; Allemand et al., 2004; Zoccola et al., 2004). The pathway of carbon transported into the calcifying fluid, however, is still a matter of debate (Marubini et al., 2008). Furla et al. (2000) proposed the involvement of an anion exchanger that we included in our model.

Since $\mathrm{CO}_{2}$ diffusion over cell membranes is a passive process, the observed functional dependence of calcification on $p \mathrm{CO}_{2}$ should be similar in most calcifying organisms. However, Ries et al. (2009) showed a huge variability in the response of different calcifiers to $p \mathrm{CO}_{2}$ changes. These include linear increase with aragonite saturation state, increase up to a maximum saturating level, non-linear responses, and linear decrease to increasing $\Omega$. Metabolic activity, i.e. respiration and photosynthesis, strongly affects the $p \mathrm{CO}_{2}$ in the microenvironment of the calcification site and the transport rates of calcium and bicarbonate into the calcifying fluid most likely differ among organisms (Ries, 2011). The relative contribution of active ion transport and $\mathrm{CO}_{2}$ diffusion into the calcifying fluid might also lead to different calcification responses to changing $p \mathrm{CO}_{2}$. This relative contribution is influenced by morphological differences among organisms (for example different sizes of the calcifying fluid). Our model has been parameterized following a specific experiment with a specific coral species. Different parameter values would therefore be required for studying calcification in other coral species.

\subsection{Carbon supply to the calcifying fluid}

Elevated $\mathrm{CO}_{2}$ diffusion can explain the decrease in coral polyp calcification at elevated seawater $p \mathrm{CO}_{2}$. However, $\mathrm{CO}_{2}$ diffusion alone is not sufficient to provide all the carbon that enters the skeleton. When in the model $\mathrm{CO}_{2}$ diffusion is considered to be the only carbon source to the calcifying fluid, we find that calcium carbonate precipitation depletes DIC to very low concentrations and calcification rates become very low. This result is consistent with the decrease in calcification rates when anion exchangers in coral polyps are inhibited (Furla et al., 2000). Calcification thus becomes carbon limited and calcium ions accumulate to unrealistically high concentrations. We therefore propose that $\mathrm{CO}_{2}$ diffusion alone is not sufficient to sustain observed calcification rates and that an additional mechanism must exist to supplement carbon into the calcifying fluid.

Our conclusion is supported by the fact that the model (1) correctly reproduces the observed changes in calcifying fluid $\mathrm{pH}$ and calcium ion concentrations (Figs. 3 and 4) and (2) shows a sustained calcification only when bicarbonate transport in symport with protons is considered. In principle, these observations might be appropriately reproduced also by assuming a carbonate ion transporter, but a bicarbonate transporter is much more likely because this is the typical transport mechanism in cell physiology (see also Furla et al., 2000).

When calcification increases during the light period, the carbon sinks exceed carbon supply and DIC concentrations in the calcifying fluid decline already way before light is switched off (Fig. 5d). The maintenance of continuous calcification is therefore the result of a fragile equilibrium between carbon supply and calcium-proton anti-transport in the coral polyp.

It is presently unclear if a paracellular pathway (Tambutté et al., 2011, 2012) plays a role in the transport of calcium and carbon into the calcifying fluid, and, if so, to which extent. Given these uncertainties, this pathway was not considered in our study. The model, however, appropriately captures the observed changes in calcium concentrations and in $\mathrm{pH}$ in the calcifying fluid, possibly suggesting a negligible role for the paracellular pathway.

\subsection{Carbonate chemistry and initial conditions}

The model qualitatively reproduces the observed time evolution of calcium concentrations and $\mathrm{pH}$ in the calcifying fluid (Figs. 3 and 4). The simultaneous changes in $\mathrm{pH}$ and calcium concentrations are coupled due to the calcium-proton antiport. Changes in $\mathrm{pH}$, however, can be buffered by the carbonate chemistry in the calcifying fluid. The initial conditions in DIC content and TA in the calcifying fluid strongly affect the time evolution of calcium and $\mathrm{pH}$. Although no direct observations are available on DIC and TA in the calcifying fluid, the high sensitivity of our model to changes in these variables provides strong constraints for inversely calculating their values in order to explain the observed changes in $\left[\mathrm{Ca}^{2+}\right]$ and $\mathrm{pH}$ (see Table 1 for initial values).

The same applies to the other model compartments. DIC and TA in the cytoplasm of the tissue, for example, are not known. Only intracellular $\mathrm{pH}$ has been determined in the range 7.1-7.4 (Venn et al., 2009). Because the ocean carbonate system (dissolved $\mathrm{CO}_{2}, \mathrm{HCO}_{3}^{-}, \mathrm{CO}_{3}^{2-}$, DIC, TA, $p \mathrm{CO} 2$, and $\mathrm{pH}$ ) has two degrees of freedom (Zeebe and Wolf-Gladrow, 2001), the whole carbonate system can be calculated from any two parameters, but not from just one. The system is therefore underdetermined and the combination of DIC and TA in the coral tissue had to be guessed. The time dependence of the $\mathrm{pH}$ signal provides further constraints on TA and DIC in the coral tissue because the buffering capacity of the carbonate chemistry affects the rate of $\mathrm{pH}$ changes and therefore the range in the $\mathrm{pH}$ signal. DIC and TA can then be constrained by the assumption that tissue $\mathrm{pH}$ ranges between 7.1 and 7.4 (Venn et al., 2009).

\subsection{Metabolic regulations and temperature}

The controlled conditions of Al-Horani et al. (2003)'s experiments and the actual observations represent strong constraints for our model. The composition of the seawater 
medium and temperature were not changed over investigation time and light was simply switched on and off without altering the intensity. In the model, these conditions are simulated by changing between photosynthetic $\mathrm{CO}_{2}$ fixation in the light and respiratory $\mathrm{CO}_{2}$ production in the dark. Moreover, active ion transport is assumed to take place only during light exposure. This is of course a strong simplification. While irradiance instantaneously triggers photosynthesis in the symbiotic zooxanthellae (Gattuso et al., 1999), the metabolic machinery of the coral polyp will most probably react gradually to abrupt changes in light conditions (Furla et al., 2000). This might be taken into account by resolving metabolic regulations of the coral polyp, for example by considering a dynamic energy pool that controls the activity of ion transport proteins and/or variable pools of functional proteins and energy-rich metabolites. Dynamic energy pools may lead to an improved representation of the data and improve the model's ability to predict the coral's response to combined changes in environmental conditions such as light, temperature, nutrition, and carbonate chemistry (Kleypas et al., 1999). These pools are, however, extremely difficult to constrain due to lack of quantitative observations.

The nutritional status of corals probably also affects the metabolic activity and thus ion transport in the polyps. As observed in our model, the activity of the ion transporters strongly affects the calcification rate (Fig. 7). The experiments by Al-Horani et al. (2003) are, however, run over a short time period so that the protein content of the polyp can be assumed to remain unchanged during simulation time. The nutritional status of the coral is therefore not relevant to our study.

The interaction between the polyp host and the algal symbionts may also become important when considering temperature effects on coral calcification. High temperatures induce the rejection of symbionts by the polyp, a process known as coral bleaching (Iglesias-Prieto et al., 1992; Douglas, 2003; Anthony et al., 2008). Changing temperatures will also affect the speed of the reactions in the carbonate system and possibly the activity of polyp enzymes and the respiration processes (Marshall and Clode, 2004). Since ocean acidification is expected to co-occur in concert with global warming, studies aiming to understand the combined effects of changing temperature and seawater carbonate chemistry are highly desirable.

\section{Conclusions}

Our modelling study is a mechanistic investigation of coral physiology and potential pathways of ion transport to the calcification site. We showed that $\mathrm{CO}_{2}$ diffusion to the calcifying fluid alone is not sufficient to sustain the observed calcification rates. An additional mechanism is required to transport carbon into the calcifying fluid. Following Furla et al.
(2000), we propose that this mechanism is represented by a bicarbonate transporter.

Our model shows that the decrease in coral calcification with raising seawater $p \mathrm{CO}_{2}$ is a result of increased diffusion of $\mathrm{CO}_{2}$ through the polyp tissue into the calcification site and may not depend on the abundance of carbonate ions in the growth medium as proposed, for example, for coccolithophores (Gehlen et al., 2007). The model further provides additional information on changes in DIC and TA occurring in the calcifying fluid that could not be obtained otherwise.

\section{Appendix A}

\section{Model equations}

The model equations can be generalised as follows:

$$
\begin{aligned}
y(t) & =\boldsymbol{v}(t) \\
y^{\prime}(t) & =\boldsymbol{f}(t) \\
\boldsymbol{f}(t) & =\mathbf{M} \times \boldsymbol{r}(t),
\end{aligned}
$$

where $\boldsymbol{v}(t)$ is the vector of state variables, $\boldsymbol{f}(t)$ is the flux vector that is defined by the product of the reaction vector, $\boldsymbol{r}(t)$, in which all single reactions are mathematically defined, and the flux matrix, $\mathbf{M}$, in which the reactions are assigned to the state variables and, under consideration of compartment volumes and surface areas, are summarized to the net fluxes, i.e. the time derivatives, $y^{\prime}(t)$, of the function, $y(t)$, to be solved.

\section{A1 State variables}

State variables are defined as follows.

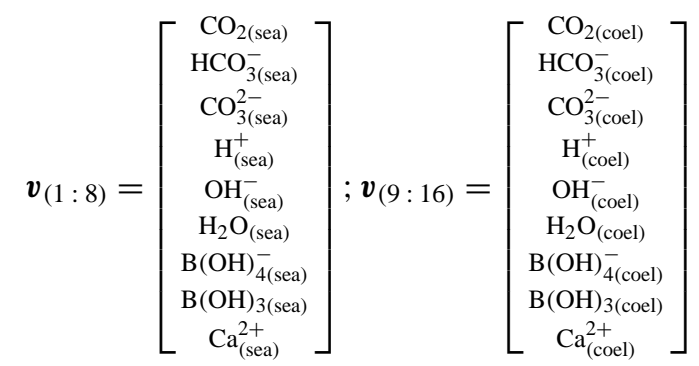

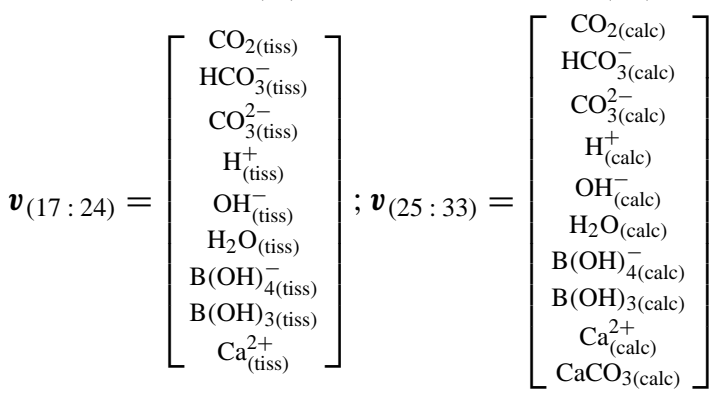

The indices (sea), (coel), (tiss), and (calc) refer to the compartments of seawater, coelenteron, tissue, and calcifying fluid, respectively. 


\section{A2 Reactions}

The chemical reactions of the carbonate system in seawater are calculated according to Zeebe and Wolf-Gladrow (2001) using 14 equations with 14 reaction rates, $k$, of the back, - , and forward, + , reactions. The reaction rates are assigned as described in Table 2.3.1, p. 110, in Zeebe and WolfGladrow (2001). The carbonate chemistry is calculated in each model compartment. For Reactions (1)-(14), the index of the involved chemicals refers to the seawater compartment, $(i)=$ (sea), whereas for Reactions (15)-(28), (29)-(42), and $(43)-(56),(i)=($ coel $),(i)=($ tiss $)$, and $(i)=($ calc $)$, respec tively (Eq. A5).

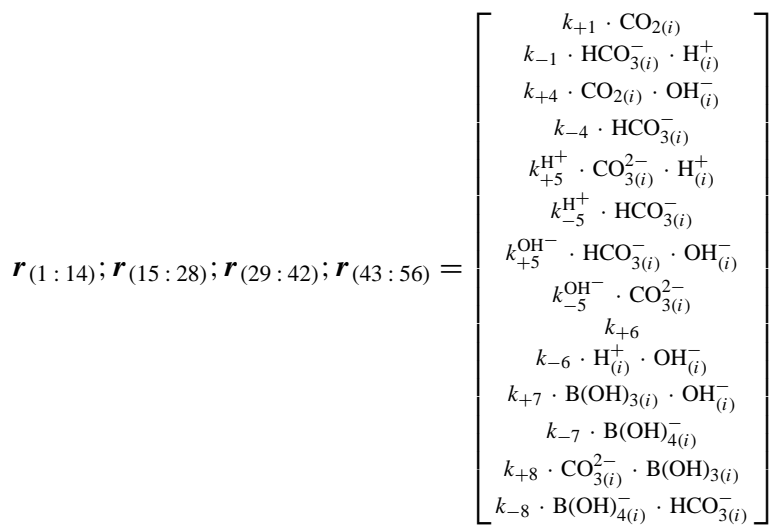

The flux of advective exchange of state variables between seawater and coelenteron is assumed to linearly depend on the concentration gradient between the two compartments with a constant exchange rate, $\omega$ (Eq. A6).

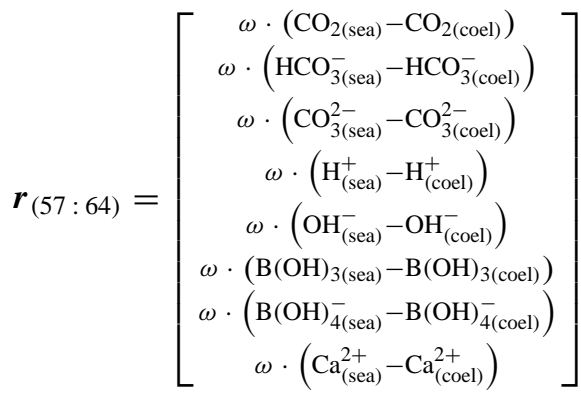

Diffusion of $\mathrm{CO}_{2}$ over compartment boundaries is parameterized according to Fick's first law of diffusion, i.e. is assumed to be driven by the concentration gradient of $\mathrm{CO}_{2}$ and the diffusion coefficient of $\mathrm{CO}_{2}$ over eukaryotic cell membranes, $\mathrm{D}_{\mathrm{CO}_{2}}$ (Eq. A7). $\mathrm{CO}_{2}$ diffusion is considered over three boundary layers, the polyp surface facing the seawater, the surface facing the coelenteron, and the layer facing the calcifying fluid.

$\boldsymbol{r}_{(65: 67)}=\left[\begin{array}{c}D_{\mathrm{CO}_{2}} \cdot\left(\mathrm{CO}_{2 \text { (sea) }}-\mathrm{CO}_{2 \text { (tiss) }}\right) \\ D_{\mathrm{CO}_{2}} \cdot\left(\mathrm{CO}_{2 \text { (coel) }}-\mathrm{CO}_{2 \text { (tiss) }}\right) \\ D_{\mathrm{CO}_{2}} \cdot\left(\mathrm{CO}_{2 \text { (tiss) }}-\mathrm{CO}_{2 \text { (calc) }}\right)\end{array}\right]$

Active bicarbonate uptake and transport over the three boundary layers of the polyp tissue are parameterized to follow simple Michaelis-Menten kinetics (Eq. A8). The maximum rate, $V_{\mathrm{HCO}_{3(\mathrm{i})}}$, can be assumed to be different for the three different pathways and therefore assigned different indices according to the compartment from which bicarbonate is removed. The half-saturation constant, $k_{\mathrm{HCO}_{3}}$, is set to be equal for all three reactions. As active transport is assumed to only occur during light exposure, the Michaelis-Menten kinetics are multiplied with a factor, $\mathcal{S}$, which acts as a light switch and is either 0 or 1 , depending on light conditions.

$\boldsymbol{r}_{(68: 70)}=\left[\begin{array}{c}\mathcal{S} \cdot\left(\frac{V_{\mathrm{HCO}_{3(\text { sea })}} \cdot \mathrm{HCO}_{3 \text { (sea) }}^{-}}{\left.k_{\mathrm{HCO}_{3}+\mathrm{HCO}_{3 \text { (sea) }}^{-}}\right)}\right. \\ \mathcal{S} \cdot\left(\frac{V_{\mathrm{HCO}_{3 \text { (coel) }} \cdot \mathrm{HCO}_{3 \text { (coel) }}^{-}}}{\left.k_{\mathrm{HCO}_{3}+\mathrm{HCO}_{3 \text { (coel) }}^{-}}\right)}\right. \\ \mathcal{S} \cdot\left(\frac{V_{\left.\mathrm{HCO}_{3(\text { tiss }}\right)} \cdot \mathrm{HCO}_{3 \text { (tiss) }}^{-}}{\left.k_{\mathrm{HCO}_{3}+\mathrm{HCO}_{3 \text { (iis) }}^{-}}^{-}\right)}\right.\end{array}\right]$

Calcium transport from the tissue into the calcifying fluid is also realized following Michaelis-Menten kinetics (Eq. A9). The entrance of calcium from the seawater and the coelenteron into the tissue is assumed to be mediated by a gated channel that uses the concentration gradient to let calcium ions diffuse into the cells. Multiplication with the light switch, $\mathcal{S}$, turns the transport on and off, according to light situations.

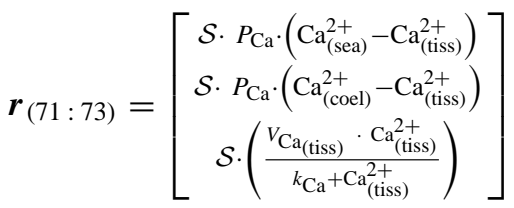

The decrease of coelenteron $\mathrm{pH}$ in the dark suggests the activity of a proton pump that acidifies the medium in the coelenteron during night for feeding and digestion (Agostini et al., 2012). For simplicity, we assume a constant rate of proton transport from the tissue to the coelenteron in the dark.

$\boldsymbol{r}_{(74)}=\left[(1-\mathcal{S}) \cdot \mathrm{H}_{\mathrm{pump}}\right]$

Photosynthesis and respiration are implemented as constant fluxes of either consumption or production of $\mathrm{CO}_{2}$ in the coral tissue. The constant rates, $C_{\text {phot }}$ and $C_{\text {resp }}$, are multiplied with the light switch, $\mathcal{S}$, or $1-\mathcal{S}$, to assure that photosynthesis occurs only during light phases and respiration only occurs in the dark (Eq. A11).

$\boldsymbol{r}_{(75: 76)}=\left[\begin{array}{c}\mathcal{S} \cdot C_{\text {phot }} \\ (1-\mathcal{S}) \cdot C_{\text {resp }}\end{array}\right]$

Calcification is implemented according to the equation proposed by Burton and Walter (1990) (Eq. A12).

$\boldsymbol{r}_{(77)}=\left[k_{p} \cdot\left(\Omega_{(\text {(calc) }}-1\right)^{n}\right]$

The saturation state of the calcifying fluid, $\Omega_{\text {(calc) }}$, with respect to aragonite, is defined by the ion product of calcium and carbonate, divided by the solubility product of aragonite, $K_{\mathrm{sp}}^{*}$ (Eq. A13). $K_{\mathrm{sp}}^{*}$ of aragonite is calculated according to Zeebe and Wolf-Gladrow (2001).

$\Omega_{\text {(calc) }}=\frac{\mathrm{Ca}_{(\text {calc })}^{2+} \cdot \mathrm{CO}_{3(\text { calc })}^{2-}}{K_{\mathrm{sp}}^{*}}$ 
Acknowledgements. We are grateful to two anonymous reviewers and to Fuad Al-Horani for constructive comments that improved the manuscript. This study was fully funded by and conducted at the Leibniz Center for Tropical Marine Ecology (ZMT) in Bremen, Germany. We intend this work as a contribution to the European Project of Ocean Acidification (EPOCA), which received funding from the European Community's Seventh Framework Programme (FP7/2007-2013) under grant agreement no. 211384.

Edited by: S. W. A. Naqvi and J.-P. Gattuso

\section{References}

Agostini, S., Suzuki, Y., Higuchi, T., Casareto, B. E., Yoshinaga, K., Nakano, Y., and Fujimura, H.: Biological and chemical characteristics of the coral gastric cavity, Coral Reefs, 31, 147-156, doi:10.1007/s00338-011-0831-6, 2012.

Al-Horani, F. A., Al-Moghrabi, S. M., and De Beer, D.: The mechanism of calcification and its relation to photosynthesis and respiration in the scleractinian coral Galaxea fascicularis, Mar. Biol., 142, 419-426, doi:10.1007/s00227-002-0981-8, 2003.

Allemand, D., Tambutte, E., Girard, J.-P., and Jaubert, J.: Organic matrix synthesis in the scleractinian coral stylophora pistillata: role in biomineralization and potential target of the organotin tributyltin, J. Exp. Biol., 201, 2001-2009, 1998.

Allemand, D., Ferrierpages, C., Furla, P., Houlbreque, F., Puverel, S., Reynaud, S., Tambutte, E., Tambutte, S., and Zoccola, D.: Biomineralisation in reef-building corals: from molecular mechanisms to environmental control, C. R. Palevol., 3, 453-467, doi:10.1016/j.crpv.2004.07.011, 2004.

Anthony, K. R. N., Kline, D. I., Diaz-Pulido, G., Dove, S., and Hoegh-Guldberg, O.: Ocean acidification causes bleaching and productivity loss in coral reef builders, P. Natl. Acad. Sci. USA, 105, 17442-17446, doi:10.1073/pnas.0804478105, 2008.

Araki, Y. and González, E. L.: V- and P-type Ca2+-stimulated ATPases in a calcifying strain of Pleurochrysis sp. (Haptophyceae), J. Phycol., 34, 79-88, 1998.

Benazet-Tambutte, S., Allemand, D., and Jaubert, J.: Permeability of the oral epithelial layers in cnidarians, Mar. Biol., 126, 43-53, 1996.

Burton, E. and Walter, L.: The role of $\mathrm{pH}$ in phosphate inhibition of calcite and aragonite precipitation rates in seawater, Geochim. Cosmochim. Ac., 54, 797-808, doi:10.1016/00167037(90)90374-T, 1990.

Caldeira, K. and Wickett, M. E.: Anthropogenic carbon and ocean pH, Nature, 425, p. 365, 2003.

Carafoli, E.: Intracellular calcium homeostasis, Annu. Rev. Biochem., 56, 395-433, 1987.

Carafoli, E.: Calcium signaling: a tale for all seasons, P. Natl. Acad. Sci. USA, 99, 1115-1122, 2002.

Chalker, B. E.: Simulating light-saturation curves for photosynthesis and calcification by reef-building corals, Mar. Biol., 63, 135141, doi:10.1007/BF00406821, 1981.

Chalker, B. E. and Taylor, D. L.: Light-enhanced calcification , and the role of oxidative phosphorylation in calcification of the coral Acropora cervicornis, P. R. Soc. B, 190, 323-331, 1975.

Clode, P. L. and Marshall, A. T.: Low temperature FESEM of the calcifying interface of a scleractinian coral, Tissue and Cell, 34, 187-198, doi:10.1016/S0040-8166(02)00031-9, 2002.
Cohen, A. L. and Holcomb, M.: Why corals care about ocean acidification: Uncovering the mechanism, Oceanography, 22, 118127, 2009.

Cohen, A. L. and McConnaughey, T. A.: Geochemical perspectives on Coral Mineralization, Rev. Mineral. Geochem., 54, 151-187, 2003.

Constantz, B. R.: Coral skeleton construction: a physiochemically dominated process, Palaios, 1, 152-157, 1986.

Cuif, J. P. and Dauphin, Y.: The Environment Recording Unit in coral skeletons - a synthesis of structural and chemical evidences for a biochemically driven, stepping-growth process in fibres, Biogeosciences, 2, 61-73, doi:10.5194/bg-2-61-2005, 2005.

Doney, S. C., Fabry, V. J., Feely, R. A., and Kleypas, J. A.: Ocean Acidification: The Other $\mathrm{CO}_{2}$ Problem, Annual Review of Marine Science, 1, 169-192, doi:10.1146/annurev.marine.010908.163834, 2009.

Douglas, A. E.: Coral bleaching - how and why?, Mar. Pollut. Bull., 46, 385-392, doi:10.1016/S0025-326X(03)00037-7, 2003.

Fautin, D. G. and Mariscal, R. N.: Cnidaria: Anthozoa, in: Placozoa, Porifera, Cnidaria, and Ctenophora, edited by: Harrison, F. W. and Westfall, J. A., 267-358, Wiley-Liss, New York, 1991.

Furla, P., Galgani, I., and Durand, I.: Sources and mechanisms of inorganic carbon transport for coral calcification and photosynthesis, J. Exp. Biol., 203, 3445-3457, 2000.

Gattuso, J.-P., Frankignoulle, M., and Bourge, I.: Effect of calcium carbonate saturation of seawater on coral calcification, Global Planet. Change, 18, 37-46, 1998.

Gattuso, J.-P., Allemand, D., and Frankignoulle, M.: Photosynthesis and Calcification at Cellular, Organismal and Community Levels in Coral Reefs: A Review on Interactions and Control by Carbonate Chemistry, Am. Zool., 39, 160-183, doi:10.1093/icb/39.1.160, 1999.

Gehlen, M., Gangstø, R., Schneider, B., Bopp, L., Aumont, O., and Ethe, C.: The fate of pelagic $\mathrm{CaCO}_{3}$ production in a high $\mathrm{CO}_{2}$ ocean: a model study, Biogeosciences, 4, 505-519, doi:10.5194/bg-4-505-2007, 2007.

Gould, G. W., East, J. M., Froud, R. J., Mcwhirter, J. M., Stefanova, H. I., and Lee, A. G.: A kinetic model for the $\mathrm{Ca}^{2+}+\mathrm{Mg}^{2+}$ activated ATPase of sarcoplasmic reticulum, Biochem. J., 237, 217-227, 1986.

Gussone, N., Langer, G., Thoms, S., and Nehrke, G.: Cellular calcium pathways and isotope fractionation in Emiliania huxleyi, Geology, 34, 625-628, doi:10.1130/G22733.1, 2006.

Helman, Y., Natale, F., Sherrell, R. M., Lavigne, M., Starovoytov, V., Gorbunov, M. Y., and Falkowski, P. G.: Extracellular matrix production and calcium carbonate precipitation by coral cells in vitro, P. Natl. Acad. Sci. USA, 105, 54-8, doi:10.1073/pnas.0710604105, 2008.

Hoegh-Guldberg, O., Mumby, P. J., Hooten, A. J., Steneck, R. S., Greenfield, P., Gomez, E., Harvell, C. D., Sale, P. F., Edwards, A. J., Caldeira, K., Knowlton, N., Eakin, C. M., IglesiasPrieto, R., Muthiga, N., Bradbury, R. H., Dubi, A., and Hatziolos, M. E.: Coral reefs under rapid climate change and ocean acidification, Science (New York, N.Y.), 318, 1737-1742, doi:10.1126/science.1152509, 2007.

Holcomb, M., Cohen, A. L., Gabitov, R. I., and Hutter, J. L.: Compositional and morphological features of aragonite precipitated experimentally from seawater and biogenically by corals, Geochim. Cosmochim. Ac., 73, 4166-4179, 
doi:10.1016/j.gca.2009.04.015, 2009.

Holcomb, M., McCorkle, D. C., and Cohen, A. L.: Long-term effects of nutrient and $\mathrm{CO}_{2}$ enrichment on the temperate coral Astrangia poculata (Ellis and Solander, 1786), J. Exp. Mar. Biol. Ecol., 386, 27-33, doi:10.1016/j.jembe.2010.02.007, 2010.

Iglesias-Prieto, R., Matta, J. L., Robins, W. A., and Trench, R. K.: Photosynthetic response to elevated temperature in the symbiotic dinoflagellate Symbiodinium microadriaticum in culture, P. Natl. Acad. Sci. USA, 89, 10302-10305, 1992.

Inesi, G.: Mechanism of calcium transport, Annu. Rev. Physiol., 47, 573-601, 1985.

Ip, Y. K., Lim, A. L. L., and Lim, R. W. L.: Some properties of calcium-activated adenosine triphosphatase from the hermatypic coral Galaxea fascicularis, Mar. Biol., 111, 191-197, 1991.

IPCC: Climate change 2007: Synthesis Report. Contribution of Working Groups I, II and III to the Fourth Assessment Report of the Intergovernmental Panel on Climate Change, Tech. rep., edited by: Core Writing Team, Pachauri, R. K. and Reisinger, A., IPCC, Geneva, Switzerland, 2007.

Kleypas, J. A., McManus, J. W., and Meñez, L. A. B.: Environmental Limits to Coral Reef Development: Where Do We Draw the Line?, Am. Zool., 39, 146-159, doi:10.1093/icb/39.1.146, 1999.

Kleypas, J., Buddemeier, R., and Gattuso, J.-P.: The future of coral reefs in an age of global change, International, J. Earth Sci., 90, 426-437, doi:10.1007/s005310000125, 2001.

Langdon, C.: Review of Experimental Evidence for Effects of $\mathrm{CO}_{2}$ on Calcification of Reef builders, in: Proc. 9th Int. Coral Reef Sym, Vol. 2, 1091-1098, 2002.

Lasaga, A. C.: Kinetic Theory in Earth Sciences, Princeton University Press, Princeton., 1998.

Leuzinger, S., Anthony, K. R. N., and Willis, B. L.: Reproductive energy investment in corals: scaling with module size, Oecologia, 136, 524-31, doi:10.1007/s00442-003-1305-5, 2003.

Lough, J. M. and Barnes, D. J.: Environmental controls on growth of the massive coral Porites, Coral Reefs, 245, 225-243, 2000.

MacLennan, D. H., Rice, W. J., and Green, N. M.: The Mechanism of $\mathrm{Ca}^{2+}$ Transport by Sarco(Endo)plasmic Reticulum $\mathrm{Ca}^{2+}$. ATPases, J. Biol. Chem., 272, 28815-28818, 1997.

Marshall, A. T. and Clode, P.: Calcification rate and the effect of temperature in a zooxanthellate and an azooxanthellate scleractinian reef coral, Coral Reefs, 23, 218-224, doi:10.1007/s00338004-0369-y, 2004.

Marshall, A. T., Clode, P. L., Russell, R., Prince, K., and Stern, R.: Electron and ion microprobe analysis of calcium distribution and transport in coral tissues., J. Exp. Biol., 210, 2453-2463, doi:10.1242/jeb.003343, 2007.

Marubini, F., Barnett, H., Langdon, C., and Atkinson, M. J.: Dependence of calcification on light and carbonate ion concentration for the hermatypic coral Porites compressa, Mar. Ecol.-Prog. Ser., 220, 153-162, doi:10.3354/meps220153, 2001.

Marubini, F., Ferrier-Pages, C., and Furla, P.: Coral calcification responds to seawater acidification: a working hypothesis towards a physiological mechanism, Coral Reefs, 27, 491-499, doi:10.1007/s00338-008-0375-6, 2008.

McCulloch, M., Falter, J., Trotter, J., and Montagna, P.: Coral resilience to ocean acidification and global warming through $\mathrm{pH}$ up-regulation, Nature Climate Change, 2, 1-5, doi:10.1038/nclimate1473, 2012.
Moya, A., Tambutte, S., Tambutte, E., Zoccola, D., Caminiti, N., and Allemand, D.: Study of calcification during a daily cycle of the coral Stylophora pistillata: implications for "light-enhanced calcification", J. Exp. Biol., 209, 3413-3419, doi:10.1242/jeb.02382, 2006.

Moya, A., Tambutté, S., Bertucci, A., Tambutté, E., Lotto, S., Vullo, D., Supuran, C. T., Allemand, D., and Zoccola, D.: Carbonic anhydrase in the scleractinian coral Stylophora pistillata: characterization, localization, and role in biomineralization, J. Biol. Chem., 283, 25475-25484, doi:10.1074/jbc.M804726200, 2008.

Orr, J. C., Fabry, V. J., Aumont, O., Bopp, L., Doney, S. C., Feely, R. A., Gnanadesikan, A., Gruber, N., Ishida, A., Joos, F., Key, R. M., Lindsay, K., Maier-Reimer, E., Matear, R., Monfray, P., Mouchet, A., Najjar, R. G., Plattner, G.-K., Rodgers, K. B., Sabine, C. L., Sarmiento, J. L., Schlitzer, R., Slater, R. D., Totterdell, I. J., Weirig, M.-F., Yamanaka, Y., and Yool, A.: Anthropogenic ocean acidification over the twenty-first century and its impact on calcifying organisms, Nature, 437, 681-686, doi:10.1038/nature04095, 2005.

Pedersen, P. L. and Carafoli, E.: Ion motive ATPases. 1. Ubiquity, properties, and significance to cell function, Trends Biochem. Sci., 12, 146-150, 1987.

Ridgwell, A., Schmidt, D. N., Turley, C., Brownlee, C., Maldonado, M. T., Tortell, P., and Young, J. R.: From laboratory manipulations to Earth system models: scaling calcification impacts of ocean acidification, Biogeosciences, 6, 2611-2623, doi:10.5194/bg-6-2611-2009, 2009.

Riebesell, U., Fabry, V. J., Hansson, L., and Gattuso, J.-P.: Guide to best practices for ocean acidification research and data reporting, Tech. rep., 2009.

Ries, J. B.: A physicochemical framework for interpreting the biological calcification response to $\mathrm{CO}_{2}$-induced ocean acidification, Geochim. Cosmochim. Ac., 75, 4053-4064, doi:10.1016/j.gca.2011.04.025, 2011.

Ries, J. B., Cohen, A. L., and McCorkle, D. C.: Marine calcifiers exhibit mixed responses to $\mathrm{CO}_{2}$-induced ocean acidification, $\mathrm{Ge}$ ology, 37, 1131-1134, doi:10.1130/G30210A.1, 2009.

Sabine, C. L., Feely, R. A., Gruber, N., Key, R. M., Lee, K., Bullister, J. L., Wanninkhof, R., Wong, C. S., Wallace, D. W. R., Tilbrook, B., Millero, F. J., Peng, T.-H., Kozyr, A., Ono, T., and Rios, A. F.: The oceanic sink for anthropogenic $\mathrm{CO}_{2}$, Science (New York, N.Y.), 305, 367-71, doi:10.1126/science.1097403, 2004.

Stolarski, J.: Three-dimensional micro-and nanostructural characteristics of the scleractinian coral skeleton: a biocalcification proxy, Acta Palaeontol. Pol., 48, 497-530, 2003.

Sueltemeyer, D. and Rinast, K.-A.: The $\mathrm{CO}_{2}$ permeability of the plasma membrane of Chlamydomonas reinhardtii: massspectrometric 18O-exchange measurements from ${ }^{13} \mathrm{C}^{18} \mathrm{O}_{2}$ in suspensions of carbonic anhydrase-loaded plasma-membrane vesicles, Planta, 200, 358-368, doi:10.1007/BF00200304, 1996.

Sueltemeyer, D., Schmidt, C., and Fock, H. P.: Carbonic anhydrases in higher plants and aquatic microorganisms, Physiol. Plantarum, 88, 179-190, doi:10.1111/j.1399-3054.1993.tb01776.x, 1993.

Szmant-Froelich, A. and Pilson, M. E. Q.: The effects of feeding frequency and symbiosis with zooxanthellae on the biochemical composition of Astrangia danae Milne Edwards \& Haime 1849, J. Exp. Mar. Biol., 48, 85-97, 1980. 
Tambutte, E., Allemand, D., Mueller, E., and Jaubert, J.: A compartmental approach to the mechanism of calcification in hermatypic corals, J. Exp. Biol., 199, 1029-1041, 1996.

Tambutté, E., Tambutté, S., Segonds, N., Zoccola, D., Venn, A., Erez, J., and Allemand, D.: Calcein labelling and electrophysiology: insights on coral tissue permeability and calcification, $\mathrm{P}$. R. Soc. B, 279, 19-27, doi:10.1098/rspb.2011.0733, 2012.

Tambutté, S., Holcomb, M., Ferrier-Pagès, C., Reynaud, S., Tambutté, E., Zoccola, D., and Allemand, D.: Coral biomineralization: From the gene to the environment, J. Exp. Mar. Biol. Ecol., 408, 58-78, doi:10.1016/j.jembe.2011.07.026, 2011.

Venn, A. A., Tambutté, E., Lotto, S., Zoccola, D., Allemand, D., and Tambutté, S.: Imaging intracellular $\mathrm{pH}$ in a reef coral and symbiotic anemone, P. Natl. Acad. Sci. USA, 106, 16574-16579, doi:10.1073/pnas.0902894106, 2009.

Venn, A., Tambutté, E., Holcomb, M., Allemand, D., and Tambutté, S.: Live Tissue Imaging Shows Reef Corals Elevate $\mathrm{pH}$ under Their Calcifying Tissue Relative to Seawater, PloS one, 6, e20013, doi:10.1371/journal.pone.0020013, 2011.
Wanninkhof, R.: Relationship Between Wind Speed and Gas Exchange Over the Ocean, J. Geophys. Res., 97, 7373-7382, 1992.

Wolf-Gladrow, D. A., Zeebe, R. E., Klaas, C., Körtzinger, A., and Dickson, A. G.: Total alkalinity: The explicit conservative expression and its application to biogeochemical processes, Mar. Chem., 106, 287-300, 2007.

Zeebe, R. E. and Wolf-Gladrow, D. A.: $\mathrm{CO}_{2}$ in Seawater: Equilibrium, Kinetics, Isotopes, Vol. 65 of Elsevier Oceanography Book Series, Elsevier, Amsterdam, 1st Edn., 2001.

Zoccola, D., Tambutté, E., Sénégas-Balas, F., Michiels, J. F., Failla, J. P., Jaubert, J., and Allemand, D.: Cloning of a calcium channel alpha1 subunit from the reef-building coral, Stylophora pistillata, Gene, 227, 157-67, 1999.

Zoccola, D., Tambutté, E., Kulhanek, E., Puverel, S., Scimeca, J.C., Allemand, D., and Tambutté, S.: Molecular cloning and localization of a PMCA P-type calcium ATPase from the coral Stylophora pistillata, Biochim. Biophys. Acta, 1663, 117-126, doi:10.1016/j.bbamem.2004.02.010, 2004. 